
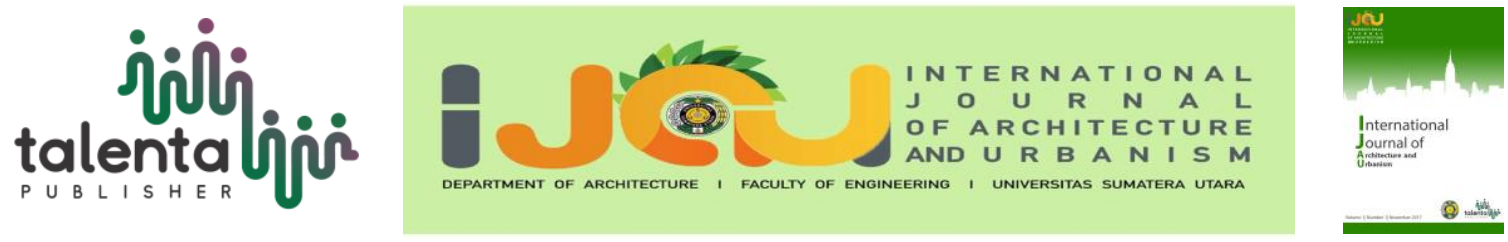

\title{
Analysis of Pedestrian Lane Users' Comfort at Padangsidimpuan
}

\author{
Novrial $^{*}$, Hammi Fadhilah Lubis ${ }^{1}$ \\ ${ }^{1}$ Architecture Departement, Faculty of Engineering, Universitas Sumatera Utara, Medan, Indonesia
}

\begin{abstract}
A convenient pedestrian lane is specifically intended for pedestrians as the main priority. Some factors which influence the comfort of the pedestrian lane are microclimate, noise, aroma, security, cleanliness, beauty. The research was done at the pedestrian lane of Padangsidimpuan by using field observation. The data were obtained from surveying and questionnaire distribution. The research used the descriptive method to describe the existing condition of the pedestrian lane. It based on its comfort and Likert scale calculation to find out the level of comfort of pedestrian lane users. The result of the research showed that the level of comfort from the factor of security, pedestrians' safety from offense had the highest value of $71 \%$, the level of offense at Padangsidsimpuan was low, and the level of comfort, from the blazing heat, had the lowest value of $41 \%$. It was because shade trees were not densely planted; they were only on the left side of the pedestrian lane so that they did not function optimally. It is recommended that the comfort of the pedestrian lane at Padangsidimpuan be increased and renewed by prioritizing the disabled people, planting trees along the pedestrian lane, and building stopping places to enable pedestrians to wait for public transportation.
\end{abstract}

Keyword: comfort, a pedestrian lane, users

\section{Introduction}

A comfortable pedestrian lane should be the priority in planning urban transportation. If it is planned well, the level of pollution and congestion in a town will decrease [1]. The comfort of a pedestrian lane can be formed through two things - climatic comfort and visual comfort. Padangsidimpuan is a town in North Sumatera Province, Indonesia. Pedestrian lane at Padangsidimpuan can be classified as a commercial one.

The existence of downtown Padangsidimpuan can be accessed easily by the townspeople, either by using their motor vehicles or by using public transportation, which makes the area full of motor vehicles which smoke causes air pollution. To decrease pollution, the townspeople need pedestrian lanes. Besides that, pedestrian lanes can increase the quality of the urban environment.

* Corresponding author at: Architecture Department, Faculty of Engineering, Universitas Sumatera Utara, StreetPerpustakaan Gedung Medan 20155, Indonesia

E-mail address: anovrial@yahoo.com 
An urban environment that is free from pollution is a town that is friendly for pedestrians by providing appropriate and adequate facilities that are comfortable and safe for pedestrians. This condition should be by a pedestrian lane in the downtown of Padangsidimpuan according to its main function, as the transportation facility of non-vehicles, especially pedestrians. The comfort of pedestrian lanes can directly increase the number of pedestrians.

Based on the explanation above, it is interesting to analyze the comfort of the pedestrian lane at Padangsidimpuan, viewed from the users' perception. That is why the researcher was motivated to research with the title, 'An Analysis on Pedestrian Lane Users' Comfort at Padangsidimpuan.' The objective of the research was to find out the environment and pedestrian lane physical condition in the downtown of Padangsidimpuan and to analyze the level of comfort according to the pedestrian lane users in the downtown of Padangsidimpuan.

\section{Literature Review}

The Comfort of Pedestrian Lane

Comfort is one of the important values which should be enjoyed by human beings in doing their activities in space [2]. Point out that some factors which influence the comfort in a pedestrian lane, among others, are microclimate, circulation, noise, aroma, shape, security, cleanliness, beauty, accessibility, and facility [3].

\section{Pedestrian}

There are two characteristics of pedestrians which have to be heeded when they are related to pedestrians' behavior, either physically or psychologically. From this theory, it can be explained that walking is an activity of moving from one place to another by enjoying the atmosphere along the road; it is also used for socialization among pedestrians so that walking becomes an enjoyable activity. For doing that activity, it is necessary to have a special pedestrian lane for walking safely and comfortably with an intimate atmosphere for pedestrians.

\section{Pedestrian Lane}

The function of a pedestrian lane is adjusted to urban development as the facility for pedestrians, urban splendor, social, interaction media, urban conservation facility, the place for relaxing, and connection with the other kinds of mode. The standard of pedestrian lanes is concerned with their width, height, and facilities. 
By using a Likert scale, the variables which have to be measured are simplified to be the indicator variable. There are two kinds of statements: a positive statement for measuring the positive scale and negative statement for measuring a negative scale.

Positive statements have scores of 5, 4, 3.2, and 1, while negative statements have scores of 1 , $2,3,4$, and 5 or $-2,-1,0,1$, and 2 . The percentage of scores is obtained by using Likert Scale formula:

$$
\%=-\mathrm{x} 100 \%
$$
(equation1)

Note $n=$ respondents' number of scores; $N=$ maximum number of scores.

\section{Methodology}

The research was done by conducting observation to get primary data, while secondary data were gathered by conducting library research. The samples were calculated by using digital software, sample size calculator by Raosoft, Inc., by margin error tolerated with $10 \%$, confident level of $90 \%$ with the assumption that the number of unknown population was 20,000. The result showed that the used samples were 68 respondents. The gathered data were analyzed by using the descriptive analysis to describe the existing condition. The perception of the questionnaires was analyzed to discuss the result of the research with a description of percentage after having added up the scores of each outcome selected by respondents. In order to simplify the analysis of data, it was necessary to find out the scores obtained by respondents from the result of filling out the questionnaires, and finally, the result of the scores was determined with the criteria of Very Comfortable (VC), Comfortable (C), Moderately Comfortable (MC), Uncomfortable (U), Very Uncomfortable (VU) (Table $1)$.

Table 1. Interval of Percentage Class of the Level of Comfort

\begin{tabular}{cl}
\hline $\begin{array}{c}\text { Interval Percentage } \\
\text { Class }(\%)\end{array}$ & \multicolumn{1}{c}{ Criteria } \\
\hline $100 \%>$ Percent $>84 \%$ & Very Comfortable $(\mathrm{VC})$ \\
\hline $84 \%>$ Percent $>68 \%$ & Comfortable $(\mathrm{C})$ \\
\hline $68 \%>$ Percent $>52 \%$ & Moderately Comfortable (MC) \\
\hline $52 \%>$ Percent $>36 \%$ & Uncomfortable $(\mathrm{U})$ \\
\hline $36 \%>$ Percent $>20 \%$ & Very Uncomfortable (VU) \\
\hline
\end{tabular}




\section{Result and Discussion}

Environmental Condition of Pedestrian Lane in Downtown of Padangsidimpuan

The downtown of Padangsidimpuan is the area which becomes the center of municipality, economy, and education. Public transportation which is directed to downtown will surely pass this street. This street area is very crowded and varied.

The downtown of Padangsidimpuan is connected to many roads so that it is easy to be accessed by the residents who use their motor vehicles or public transportation. Therefore, the area of the pedestrian lane in Downtown of Padangsidimpuan is classified as a commercial pedestrian lane, which is very crowded. Right in downtown, there is an esplanade which is called, Alaman Bolak and Tugusalak.

The latter is the icon of the town, and many residents use it as an amusement park or a place for relaxing. It usually begins to be crowded at about 5:00 PM until late at night (Figure 1).

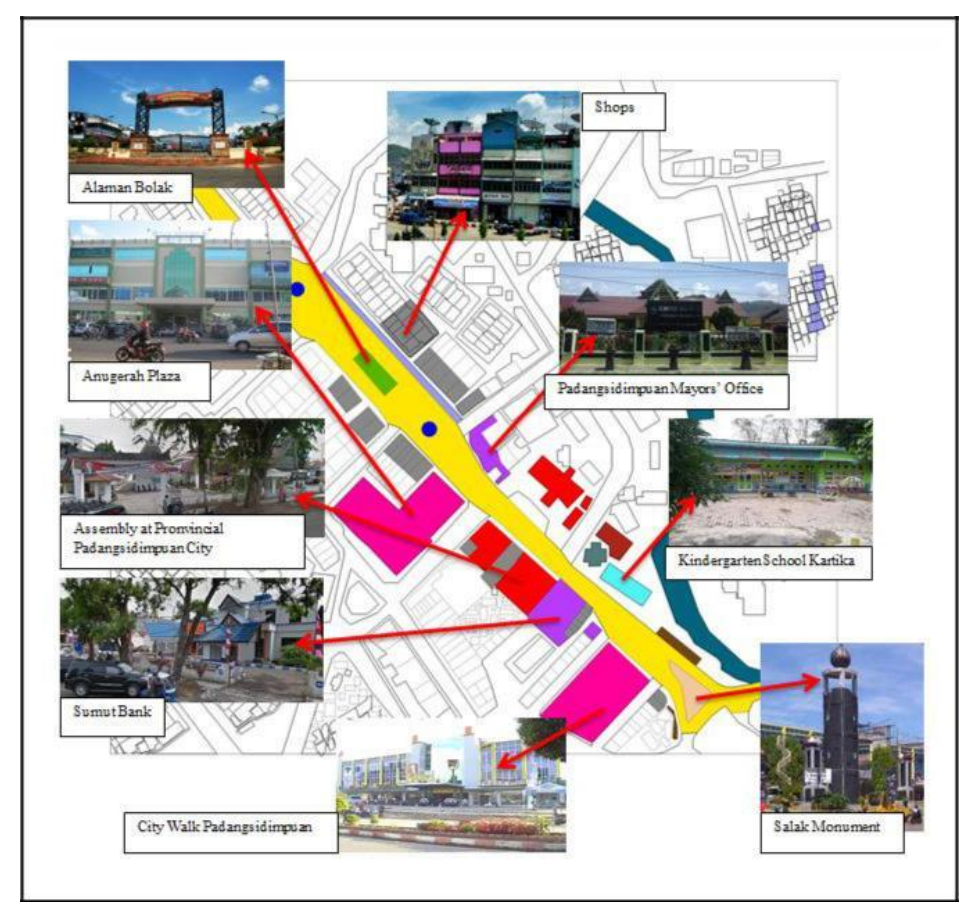

Figure 1. Buildings Surrounding Pedestrian Lane

The Condition of Pedestrian Lane

The width of Pedestrian Lane in the downtown of Padangsidimpuan is 1.5 meters, and it is by the standard of the width of the pedestrian lane, based on the number of pedestrians according to the Decree of the Minister of Transportation No. KM. 65/1993. The height of the pedestrian lane in the downtown of Padangsidimpuan is 38 centimeters. The ideal height of the pedestrian lane is maximally 30 centimeters from the road surface, which means that 
the pedestrian lane in downtown has surpassed the ideal height of the pedestrian lane (Figure 2).

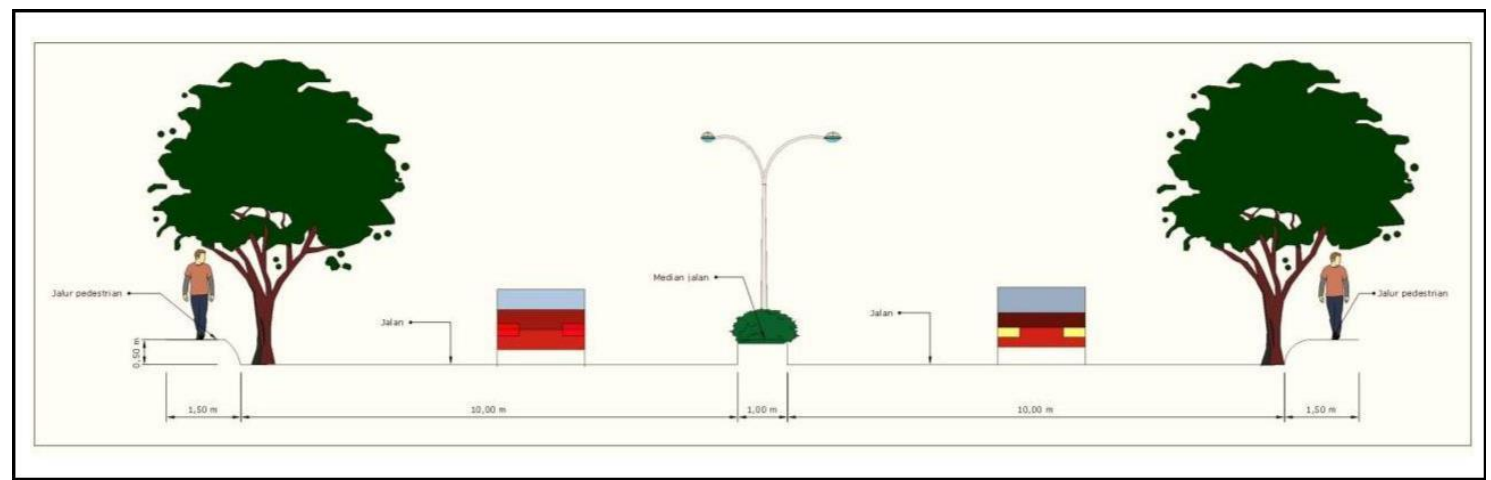

Figure 2. The dimension of Pedestrian Lane in Downtown of Padangsidimpuan

Pedestrian lane in the downtown of Padangsidimpuan is functioned not only for pedestrians but also as the space for waiting for public transportation, the space for street vendors, and the space for relaxing.

The condition of the surface of the pedestrian lane has met the requirements: hard, flat, and not slippery. The hardening of the pedestrian lane uses natural ceramic material (Figure 3).

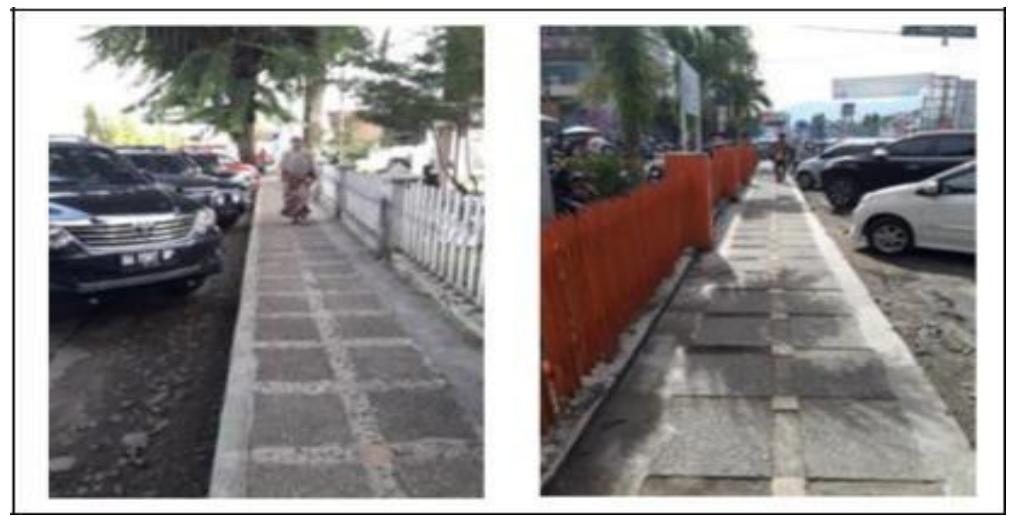

Figure 3. Pedestrian Lane in Downtown of Padangsidimpuan

The random location of street furniture causes pedestrian lanes to be narrow. There are some flower pots and trash boxes put on the pedestrian lane, in front of the Town Hall (Figure 4).

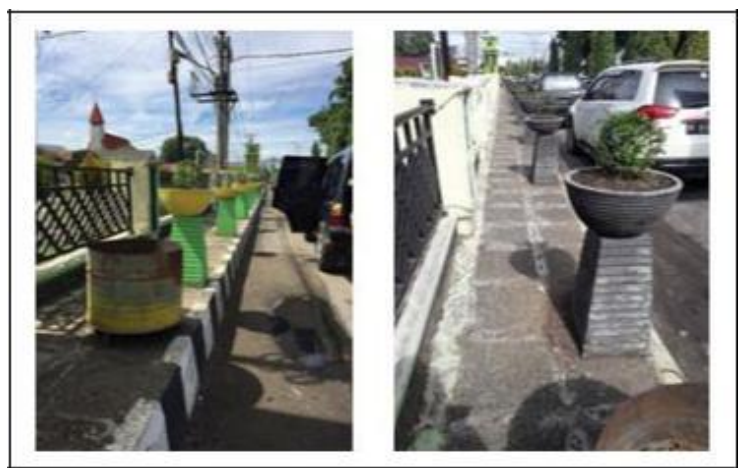

Figure 4. Random Location of Furniture 
The area for relaxing is not planted by shade trees so that people are exposed directly to the sunlight. Therefore, pedestrians would rather choose to sit down under the shady trees on the pedestrian lane (Figure 5).

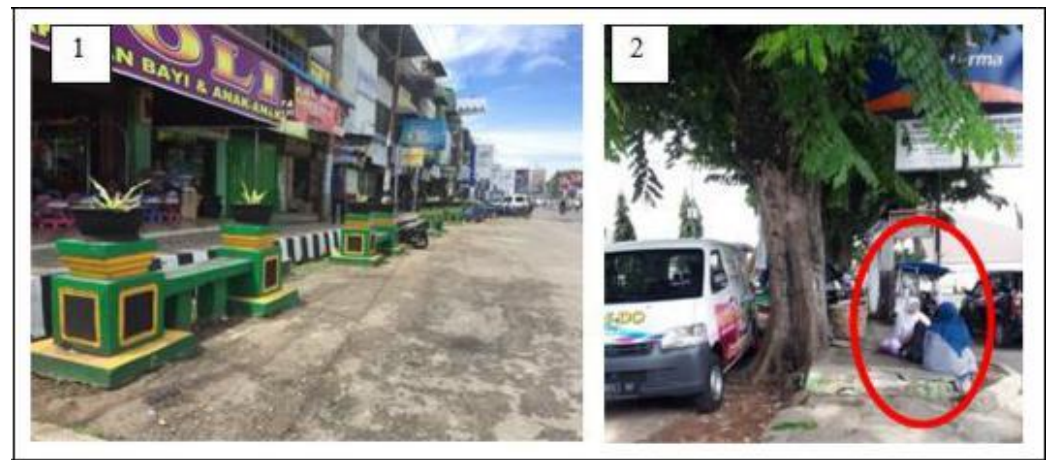

Figure 5. (1) Area for Relaxing, (2) Pedestrian sits down on Pedestrian Lane.

Analysis of Result of Questionnaires

The result of the research indicated that the scores obtained from the survey were presented in the form of a percentage of respondents' perception based on the condition of the pedestrian lane (Table 2). The calculation of the percentage of the perception of the condition of the pedestrian lane used simple statistics with the figure processing device, SPSS Statistic 17.0.

Table 2. Respondents' Perception Based on the Condition of Pedestrian Lane

\begin{tabular}{lllllll}
\hline NO & $\begin{array}{l}\text { Condition of pedestrian lane in } \\
\text { downtown of Padangsidimpuan }\end{array}$ & VU & U & MC & C & VC
\end{tabular}

\begin{tabular}{lllllll}
\hline 1. & Microclimate (blazing heat) & $23,5 \%$ & $45,6 \%$ & $30,9 \%$ & $0 \%$ & $0 \%$ \\
\hline 2. & Microclimate (rainfall) & $7,4 \%$ & $38,2 \%$ & $42,6 \%$ & $11,8 \%$ & $0 \%$ \\
& & & & & & \\
\hline
\end{tabular}

3.

Circulation clarity between

\begin{tabular}{|c|c|c|c|c|c|c|}
\hline & $\begin{array}{l}\text { pedestrians and other activities } \\
\text { (Street vendors, parking lots, etc.) }\end{array}$ & $19,1 \%$ & $29,4 \%$ & $39,7 \%$ & $11,8 \%$ & $0 \%$ \\
\hline 4. & Noises of vehicles & $0 \%$ & $17,6 \%$ & $54,4 \%$ & $27,9 \%$ & $0 \%$ \\
\hline 5. & Aroma/bad smells & $0 \%$ & $26,5 \%$ & $38,2 \%$ & $32,4 \%$ & $2,9 \%$ \\
\hline 6. & Hardening shape and quality & $0 \%$ & $16,2 \%$ & $50,0 \%$ & $25,0 \%$ & $8,8 \%$ \\
\hline 7. & Secured from offenses & $0 \%$ & $7,4 \%$ & $50,0 \%$ & $23,5 \%$ & $\begin{array}{l}19,1 \\
\%\end{array}$ \\
\hline$\overline{8 .}$ & Secutiry of pedestrian lane & $0 \%$ & $22,1 \%$ & $35,3 \%$ & $27,9 \%$ & $\begin{array}{l}14,7 \\
\%\end{array}$ \\
\hline 9. & Cleanliness of pedestrian lane & $1,5 \%$ & $26,5 \%$ & $33,8 \%$ & $32,4 \%$ & $5,9 \%$ \\
\hline$\overline{10 .}$ & The beauty of pedestrian lane & $1,5 \%$ & $23,5 \%$ & $44,1 \%$ & $26,5 \%$ & $4,4 \%$ \\
\hline 11. & Accessibility & $0 \%$ & $5,9 \%$ & $67,6 \%$ & $19,1 \%$ & $7,4 \%$ \\
\hline$\overline{12 .}$ & Completion of facilities & $22,1 \%$ & $33,8 \%$ & $39,7 \%$ & $4,4 \%$ & $0 \%$ \\
\hline
\end{tabular}


Research Discussion

From the result of the research from the questionnaires, it is found the perception of the pedestrian lane users on the condition now in the pedestrian lane in the downtown of Padangsidimpuan. Table 3 below shows the percentage of the level of comfort in the pedestrian lane in the downtown of Padangsidimpuan.

Table 3. Level of Comfort in Pedestrian Lane

\begin{tabular}{|c|c|c|c|c|}
\hline No. & Condition in Pedestrian Lane & Score & $\%$ & Category \\
\hline$\overline{1 .}$ & Microclimate (blazing heat) & 141 & $41 \%$ & Uncomfortable \\
\hline 2. & Microclimate (rainfall) & 176 & $51 \%$ & Uncomfortable \\
\hline 3. & Circulation clarity & 166 & $49 \%$ & Uncomfortable \\
\hline$\overline{4 .}$ & Noises of vehicles & 211 & $62 \%$ & Moderately comfortable \\
\hline 5. & Aroma/bad smells & 212 & $62 \%$ & Moderately comfortable \\
\hline 6. & Hardening shape and quality & 222 & $65 \%$ & Moderately comfortable \\
\hline 7. & Secured from offenses & 241 & $71 \%$ & Comfortable \\
\hline 8. & Security of pedestrian lane & 228 & $67 \%$ & Moderately comfortable \\
\hline 9. & Cleanliness of pedestrian lanes & 214 & $63 \%$ & Moderately comfortable \\
\hline 10. & $\begin{array}{l}\text { The beauty of materials a } \\
\text { shape }\end{array}$ & 210 & $61 \%$ & Moderately comfortable \\
\hline 11. & Accessibility & 223 & $65 \%$ & Moderately comfortable \\
\hline$\overline{12 .}$ & Completion of facility & 154 & $45 \%$ & Uncomfortable \\
\hline
\end{tabular}

Based on Table 3 above, it is found that blazing heat and microclimate are categorized as uncomfortable. The clarity of the circulation in the the pedestrian lane in the downtown of Padangsidimpuan is not comfortable because there are still street vendors selling their merchandise on it. Viewed from the factor of aroma/smell, the pedestrian lane in the downtown of Padangsidimpuan is in the category of comfort even though there are still trash boxes which are not in order since the garbage is not taken out.

Cleanliness highly influences one's comfort. A human being tends to choose something which is clean rather than the dirty one, and it is true to the pedestrian lane. Its Users surely choose to walk on a clean pedestrian lane rather than walking on a dirty and messy one, let alone if the garbage stinks. The purpose of this statement is to find out the opinion of the pedestrian lane users about the hygienic condition of a pedestrian lane. The cleanliness of pedestrian lane in the downtown of Padangsidimpuan is in the category of comfort.

Beauty is the factor of comfort related to the visual matter. The purpose of this statement is to find out respondents' appraisal of the beauty of a pedestrian lane. The beauty of the pedestrian lane in the downtown of Padangsidimpuan is categorized as comfortable, viewed from its shape, color, the arrangement of the garden, and human activity on it. 
Another factor of comfort, according to the respondents and based on Picture 6, the highest score for comfort, and the increase in the quality of the pedestrian lane is security. Of the 68 respondents, $41 \%$ of them say that security is the factor which brings about comfort. Therefore, they expect that to increase comfort in the pedestrian lane in the downtown of Padangsidimpuan should be done by improving damaged facilities and adding shade trees.

\section{Conclusion}

Based on the result of the analysis, it can be concluded that: Physical condition of the pedestrian lane is as follows: its width is 1.50 meters which indicate that it has met the standard stipulated in the Decree of the Minister of Transportation No. 65/1993, intended for 2 (two) pedestrians.

The height of the pedestrian lane from its surface is 38 centimeters which its ideal height is maximally 30 centimeters, which indicates that its height is more than the standard of ideal height. From the calculation of the descriptive percentage analysis on the condition of the pedestrian lane, it is indicated that respondents feel moderately comfortable (MC) doing their activities on the pedestrian lane.

Some factors which are expected by the respondents to increase the comfort in the pedestrian lane in the downtown of Padangsidimpuan are the addition of shade trees to reduce the blazing heat of the sun during the day and improvement of its facilities.

\section{Acknowledgment}

This article was prepared by researchers as a part of finding by Universitas Sumatera Utara to City Government to dedicate expertise in the field of architecture based on local wisdom in planning and design.

\section{REFERENCES}

[1] M. Muslihun, Studi Kenyamanan Pejalan Kaki Terhadap Pemanfaatan Jalur Pedestrian Di Jalan Protokol Kota Semarang (Studi Kasus Jl. Pahlawan), Semarang: Universitas Semarang, 2013.

[2] N. Anggriani, Pedestrian Ways Dalam Perancangan Kota, Klaten: Yayasan Humaniora, 2009.

[3] Rustam Hakim. Hardi Utomo, Komponen Perancangan Arsitektur Lansekap, Jakarta: Bumi Aksara, 2003. 